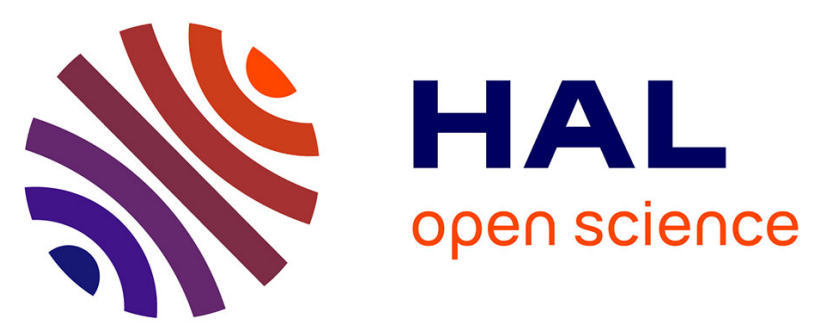

\title{
Design and Integration in Electro-Optic Devices of Highly Efficient and Robust Red-NIR Phosphorescent Nematic Hybrid Liquid Crystals Containing [Mo6I8(OCOCnF2n+1)6]2- $(\mathrm{n}=1,2,3)$ Nanoclusters Marianne Prévôt, Maria Amela-Cortes, Sumann K Manna, Ronan Lefort, Stéphane Cordier, Hervé Folliot, Laurent Dupont, Yann Molard
}

\section{To cite this version:}

Marianne Prévôt, Maria Amela-Cortes, Sumann K Manna, Ronan Lefort, Stéphane Cordier, et al.. Design and Integration in Electro-Optic Devices of Highly Efficient and Robust Red-NIR Phosphorescent Nematic Hybrid Liquid Crystals Containing [Mo6I8(OCOCnF2n+1)6]2- $(\mathrm{n}=1,2,3)$ Nanoclusters. Advanced Functional Materials, 2015, 25 (31), pp.4966-4975. 10.1002/adfm.201501876 . hal-01180052

\section{HAL Id: hal-01180052 \\ https://hal.science/hal-01180052}

Submitted on 13 Jan 2016

HAL is a multi-disciplinary open access archive for the deposit and dissemination of scientific research documents, whether they are published or not. The documents may come from teaching and research institutions in France or abroad, or from public or private research centers.
L'archive ouverte pluridisciplinaire HAL, est destinée au dépôt et à la diffusion de documents scientifiques de niveau recherche, publiés ou non, émanant des établissements d'enseignement et de recherche français ou étrangers, des laboratoires publics ou privés. 


\section{Design and integration in electro-optic devices of highly efficient and robust red NIR phosphorescent nematic hybrid liquid crystals containing $\left[\mathrm{Mo}_{6} \mathrm{I}_{8}\left(\mathrm{OCOC}_{n} \mathrm{~F}_{2 n+1}\right)_{6}\right]^{2-}(\mathrm{n}=1,2,3)$ nanoclusters.}

Marianne Prévôt, Maria Amela-Cortes, Sumann K. Manna, Ronan Lefort, Stéphane Cordier, Hervé Folliot, Laurent Dupont* and Yann Molard*

Marianne Prévôt, Dr. Maria Amela-Cortes, Dr. Stéphane Cordier, Dr. Yann Molard

Université de Rennes 1- CNRS UMR 6226 "Institut des Sciences Chimiques de Rennes“, Campus de Beaulieu, CS 74205, 35042 Rennes

Cedex, France

E-mail: yann.molard@univ-rennes1.fr

Sumann K. Manna, Pr. Laurent Dupont

Département d'optique Télécom Bretagne, Brest, France

E-mail: laurent.dupont@telecom-bretagne.eu

Dr. Ronan Lefort

Université de Rennes 1, UMR Institut de Physique de Rennes, UR1-CNRS 6626, Campus de Beaulieu, CS 74205, 35042 Rennes Cedex, France

Marianne Prévôt, Pr. Hervé Folliot

Université Européenne de Bretagne, INSA, FOTON, UMR 6082, F-35708 Rennes, France

Keywords: hybrid materials, liquid crystals, photoluminescence, electro-optic materials 
By combining $\left[\mathrm{Mo}_{6} \mathrm{I}_{8}\left(\mathrm{C}_{\mathrm{n}} \mathrm{F}_{2 \mathrm{n}+1} \mathrm{COO}\right)_{6}\right]^{2-}(\mathrm{n}=1,2,3)$ nanocluster units with liquid crystalline ammonium cations, we developed a new series of hybrid materials that show a nematic liquid crystal phase, the most fluid of all LC phase, on a large range of temperatures including room temperature. The photophysical studies performed in the LC state have shown that these self-assembled hybrid materials emit in the Red-NIR with absolute quantum yields up to 0.7 and show a very good photostability under continuous irradiation. They were further integrated up to 20 $\mathrm{wt} \%$ in E7, a well-known nematic commercial LC mixture. Mixtures were investigated in terms of homogeneity and stability to select the best suitable candidate for the design of electro-controlled devices. Studies of optical switching, contrast, viscosity and behavior toward an electrical stimulus, demonstrate the high potential of these hybrid materials in the fields of photonic or optoelectronic.

\section{Introduction}

Liquid crystals (LC) have a big impact on our everyday life. They are most of the time associated to display technology, ${ }^{[1]}$ but can also be found in many other applications where electron, ion, or molecular transporting are necessary, or in the fields of holography, spectroscopy, or biomedical. ${ }^{[2]}$ Beside their abilities to selfassemble, they are also very well known as smart materials to respond easily to external stimuli such as a change of temperature, application of a magnetic or electric field. Thus, conferring new functionalities like luminescence, redox states and/or magnetism to $\mathrm{LC}$ is a challenge of particular interest to design new materials that would improve the efficiency of existing technologies or develop new ones. ${ }^{[3]}$ In particular, photoluminescent materials play a key role in photonics, optoelectronics or lighting applications. ${ }^{[4]}$ In this frame, inorganic luminophores appear as the most appropriate materials in terms of stability as compared to organic compounds which suffer from photobleaching. Thus, luminescent transition metals, ${ }^{[3 a, 3 c, 5]}$ lanthanide(III) ${ }^{[3 \mathrm{~d}, 6]}$ quantum dots or nanoparticle ${ }^{[7]}$ have been introduced in LC giving birth to metallomesogens and liquid crystal nanosciences. ${ }^{[5,8]}$

Recently we discovered a new class of luminescent hybrid LC material called clustomesogen that contains transition metal clusters. ${ }^{[9]}$ These inorganic entities were defined by F.A. Cotton as a finite group of metal atoms linked together by metal-metal bonds and are obtained, as ceramic-like powders, by high temperature solid state synthesis. ${ }^{[10]}$ So far, three strategies were developed to design clustomesogens: i) a covalent approach in which organic LC promoters are covalently linked on an octahedral metallic cluster core, ii) a supramolecular one that combines electrostatic and host guest interactions to associate the $\mathrm{LC}$ organic promoters with an alkali $\mathrm{Cs}_{2} \mathrm{Mo}_{6} \mathrm{Br}_{14}$ ternary salt, and, iii) an ionic approach that takes advantage of the cluster units anionic character to associate them with organic cations bearing the mesogenic promoters. Indeed, the octahedral $\left.\left[\mathrm{M}_{6} \mathrm{X}_{8}^{\mathrm{i}} \mathrm{X}_{6}\right]^{\mathrm{a}}\right]^{\mathrm{n}}$ cluster units $(\mathrm{M}=\mathrm{Mo}, \mathrm{W}$, or Re; $\mathrm{X}^{\mathrm{i}}=$ chalcogen/halogen; $\mathrm{X}^{\mathrm{a}}=$ halogen; $\mathrm{i}=$ inner, $\mathrm{a}=$ apical, $\left.\quad 2 \leq \mathrm{n} \leq 4\right)$ exhibit emission in the red-NIR area upon excitation in the UV-blue with high photoluminescence quantum yields and possess excited state lifetimes in the range of several tenths of microseconds, thanks to the full delocalization of their valence electrons on the all metallic octahedral scaffold. ${ }^{[1]}$ These last decades, many efforts have been dedicated to their integration in supramolecular architectures, polymeric frameworks or nanomaterials that take advantage of their intrinsic properties. ${ }^{[12]}$ Very recently, highly luminescent cluster compounds were reported in the literature. They are made of a rigid octahedral $\mathrm{Mo}_{6}$ scaffold surrounded by eight iodine inner ligands. Their six apical positions are occupied by short fluoroalkyloate ligands linked via single Mo-O bonds. ${ }^{[13]}$

Using such inorganic light bulb appears as particularly appealing to design strongly emitting hybrid LC materials. To do so, previous studies have shown that the cluster unit must keep its integrity within the material in order to retain its fullest ability to emit light. From this point of view, the supramolecular and ionic strategies seem the most promising techniques to generate new highly luminescent clustomesogens. We present in this work a full study starting from the design of the molecular material up to its introduction in a device suitable for optoelectronic applications. To obtain such applicative material, it is mandatory to design hybrid materials that show a high fluidity. Indeed, they have to be able to respond as fast as possible to an external stimulus such as the application of an electric or magnetic field. The nematic phase being the most fluid of all LC phase, a particular attention has been drawn in this work to design hybrid materials presenting such phase.

\section{Results and discussion}

\subsection{Synthesis}

Mesomorphic hybrid compounds are made of $\left[\mathrm{Mo}_{6} \mathrm{I}_{8}\left(\mathrm{C}_{\mathrm{n}} \mathrm{F}_{2 \mathrm{n}+1} \mathrm{COO}\right)_{6}\right]^{2-}$ $(\mathrm{n}=1,2$ or 3$)$ cluster units associated with trialkylmethylammonium counter-cations bearing cyanobiphenyl terminated decyloxy chains (Scheme 1). They were obtained after a metathesis reaction between the corresponding cluster unit cesium salt and the brominated ammonium
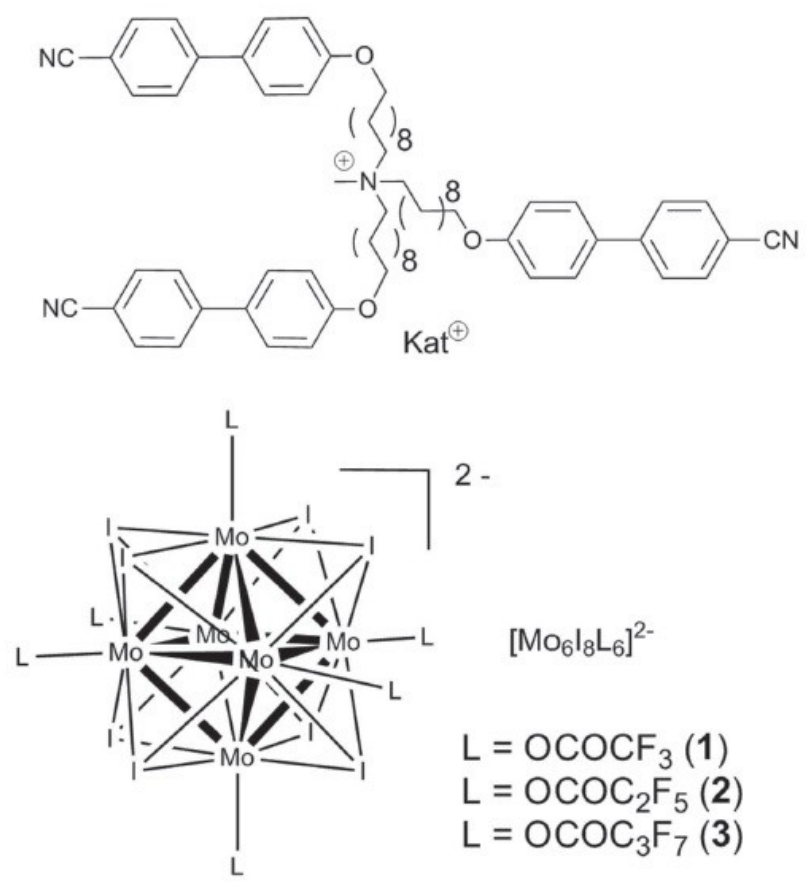

Scheme 1. General representation of octahedral molybdenum cluster units and of the organic promesomorphic cation Kat ${ }^{+}$used in this study.

organic one. Cluster compounds $\mathrm{Cs}_{2} \mathrm{Mo}_{6} \mathrm{I}_{8}\left(\mathrm{OCOC}_{\mathrm{n}} \mathrm{F}_{2 \mathrm{n}+1}\right)_{6}$ were chosen for two main reasons: i) their excellent photophysical properties as recently reported by Sokolov et al. ${ }^{[13 \mathrm{a}]}$ for $\left(n \mathrm{Bu}_{4} \mathrm{~N}\right)_{2} \mathrm{Mo}_{6} \mathrm{I}_{8}\left(\mathrm{OCOC}_{3} \mathrm{~F}_{7}\right)_{6}$ and Kirakci et al. ${ }^{[13 b]}$ for $\left(n \mathrm{Bu}_{4} \mathrm{~N}\right)_{2} \mathrm{Mo}_{6} \mathrm{I}_{8}\left(\mathrm{OCOCF}_{3}\right)_{6}$. Indeed, quantum yields of 0.59 and 1 were reported in solution for these two cluster compounds, respectively; ii) in the frame of clustomesogen chemistry, we wanted to explore the influence of the cluster apical ligands length on the liquid crystal properties of the resulting hybrid. The cluster units were prepared from $\mathrm{Cs}_{2} \mathrm{Mo}_{6}{ }_{6}{ }_{8}{ }^{\mathrm{i}} \mathrm{I}_{6}{ }_{6}$ and $\mathrm{AgOCOC}_{n} \mathrm{~F}_{2 \mathrm{n}+1}$ respectively. $\mathrm{Kat}^{+}$was obtained as a bromide salt form, according to reported procedure. ${ }^{[14]}$ In all cases, a stoichiometric amount of Kat-Br dissolved in dichloromethane was used in the metathesis reaction to exchange the alkali counter-cations associated with the cluster unit solubilized in acetone (see the experimental part for further details). Hybrid compounds were characterized by ${ }^{1} \mathrm{H}$ NMR, ${ }^{19} \mathrm{~F}$ NMR, energy dispersive spectroscopy (EDS) and elemental analysis. ${ }^{1} \mathrm{HNMR}$ spectra of hybrids are very similar to the parent organic salt $\mathrm{KatBr}$; only a slight shift to higher field (around $0.3 \mathrm{ppm}$ ) of signals corresponding to protons in $\alpha$ position of the ammonium head $\mathrm{N}$ atom is observed. Elemental analysis measurements confirmed the purity of compounds. 
Residual solvent molecules that could not be removed upon heating at $60^{\circ} \mathrm{C}$ under vacuum were found for compound (3). This phenomenon is quite usual for supermolecular systems and has already been reported by others. ${ }^{[15]}$

\subsection{Self-assembling abilities}

The mesomorphic properties of hybrid compounds were investigated by polarized optical microscopy (POM), differential scanning calorimetry (DSC) and small angle X-ray scattering (SAXS). Results are summarized in Table 1. Fluoro substituents inserted in metallomesogens were reported in the literature as entities that may modify melting point or transition temperatures. ${ }^{[16]}$ Here, no significant change of these parameters within our series of compounds was observed. The thermal behavior was observed by DSC at a heating or cooling rate of $10^{\circ} \mathrm{C} . \mathrm{min}^{-1}$ during three heating/cooling cycles. All DSC traces were superimposable except for the one corresponding to the first heating that reflects the usual complicated thermal behavior of supramolecular systems with several endo or exothermic signals. ${ }^{[17]}$ From the first cooling, DSC traces appeared mostly silent and only a glass transition around $20^{\circ} \mathrm{C}$ was observable (see ESI, Figures S1-S3), except for $\mathrm{Kat}_{2}\left[\mathrm{Mo}_{6} \mathrm{I}_{8}\left(\mathrm{OCOC}_{2} \mathrm{~F}_{5}\right)_{6}\right]$. For this compound, a very weak and large exothermic event relative to the isotropic to liquid crystalline state transition could be detected, only on cooling, between $76^{\circ} \mathrm{C}$ and $64^{\circ} \mathrm{C}$. Thus, the isotropic-LC phase transition temperatures reported in Table 1 were determined by POM and were confirmed by temperature dependent luminescence spectroscopy (vide infra). Hybrid compounds were deposited between two glass slides. By applying a gentle mechanical stress on cooling from the isotropic, flashes appeared followed by schlieren textures that started to become persistent on cooling around $60^{\circ} \mathrm{C}$. These are in good accordance with the formation of a nematic phase (see ESI, Figure S4).

Table 1. Phase behavior and transition temperatures of obtained compounds taken from the $1^{\text {st }}$ cooling.

\begin{tabular}{lll}
\hline & $\mathrm{LC}$ & $\mathrm{T}\left[{ }^{\circ} \mathrm{C}\right]$ \\
\hline $\mathrm{Kat}_{2}\left[\left.\mathrm{Mo}_{6}\right|_{8}\left(\mathrm{CF}_{3} \mathrm{COO}\right)_{6}\right]$ & $\mathrm{I}-\mathrm{N}$ & $64^{\mathrm{a}}$ \\
& $\mathrm{N}-\mathrm{g}$ & 22 \\
$\mathrm{Kat}_{2}\left[\mathrm{Mo}_{6} \mathrm{I}_{8}\left(\mathrm{C}_{2} \mathrm{~F}_{5} \mathrm{COO}\right)_{6}\right]$ & $\mathrm{I}-\mathrm{N}$ & 64 \\
& $\mathrm{~N}-\mathrm{g}$ & 20 \\
$\mathrm{Kat}_{2}\left[\mathrm{Mo}_{6} \mathrm{I}_{8}\left(\mathrm{C}_{3} \mathrm{~F}_{7} \mathrm{COO}\right)_{6}\right]$ & $\mathrm{I}-\mathrm{N}$ & $61^{\mathrm{a}}$ \\
& $\mathrm{N}-\mathrm{g}$ & 19
\end{tabular}

${ }^{\mathrm{a}}$ Temperature determined by microscopy; I: isotropic, N: nematic, $\mathrm{g}$ : glass.

The X-ray diffraction patterns recorded at different temperatures for the three hybrids are all qualitatively equivalent and in good accordance for (2) and (3) with the nematic character of the observed phases (see ESI Figures S5-S7). Two broad scattering signals indicative of short range orders were recorded in the low angle region. They are attributed to the intermolecular short-range interactions that are parallel $\left(\mathrm{d}_{1}=31.9 \AA, 28.7 \AA\right.$ or $32.9 \AA$ for $\mathrm{n}=$ 1,2 or 3 respectively, at $\left.50^{\circ} \mathrm{C}\right)$ and perpendicular $\left(\mathrm{d}_{2}=15.0 \AA, 14.2\right.$ $\AA$ or $14.2 \AA$ for $n=1,2$ or 3 respectively at $50^{\circ} \mathrm{C}$ ) to the molecular long axis. Their positions were determined by fitting the $\left[0.15 \AA^{-1}\right.$ $\left.0.6 \AA^{-1}\right]$ area of all diffractograms with two lorentzian peaks (see ESI Table S1) and are in good accordance with previously reported results. ${ }^{[9 c, 17]}$ Taking in consideration the experimental error, these signals might also be interpreted as corresponding to a short range layered morphology with a reciprocal spacing in the 1:2 ratio which would underline the cybotactic character of the observed nematic phases. In this case, lowering the temperature should induce a shift to lower angle for both signals which does not appear to be the case according to fitting results. Indeed, lowering the temperature leads to a logical increase of $d_{1}$ due to the rigidification of the ammonium cation akyl chains but to a slight decrease of $d_{2}$ which shows that $d_{1}$ and $\mathrm{d}_{2}$ are not in the 1:2 ratio. A broad and weak scattering located at $\mathrm{q}=$ $1.15 \AA^{-1}(\mathrm{~d}=5.43 \AA)$ is also observed and corresponds to the perfluorinated chains interactions between clusters apical ligands. ${ }^{[18]}$ For (1), an additional sharper signal at $\mathrm{q}=1.54 \AA^{-1}(\mathrm{~d}=4.02 \AA)$ can be observed. Its intensity is slightly reduced in the isotropic state but, due to experimental set-up limitations, it was not possible to heat the sample up to its complete disappearance. Such scattering may correspond to a partial crystallization of the aliphatic chains and thus contrasts with the fluidity and schlieren texture observed by POM. However, the miscibility of (1) with commercial nematic E7 is a good indication of the nematic nature of the observed mesophase (vide infra). At this stage, we would like to emphasize that the nematogenic character observed for (2) and (3) on a so wide temperature range (around $40^{\circ} \mathrm{C}$ ) is surprising compared to ionically self-assembled hybrid systems outlined in the literature ${ }^{[19]}$ By using our synthetical approach, we already observed this behavior by combining $\left[\mathrm{Mo}_{6} \mathrm{Br}_{8}^{\mathrm{i}}(\mathrm{CN})^{\mathrm{a}}{ }_{6}\right]^{2-}$ with $\mathrm{Kat}^{+}{ }^{[9 \mathrm{c}]}$ In this case, the nematic phase was observed only on a very short temperature range $\left(7^{\circ} \mathrm{C}\right)$. Therefore, hybrid compounds described in this work are one of the very few representatives of nematogenic ionic liquid crystals ${ }^{[20]}$ and are, to the best of our knowledge, the only known that cover a large temperature range including room temperature.

\subsection{Photophysical properties}

Photophysical properties were investigated in acetonitrile solution for absorption measurements (ESI, Figure S8) and in the solid glassy or liquid crystalline state for all hybrids. Absorption spectra are mainly composed by the $\mathrm{Kat}^{+}$absorption bands that contains the highly UVabsorbing CB units. A careful look in the $400-500 \mathrm{~nm}$ area shows weak bands assigned to the metallic cluster to ligand charge transfer transitions. As expected, no significant differences due to the perfluoroalkylated chain length is observed.

In previous works, ${ }^{[9]}$ we demonstrated the high potential of clustomesogen by the preservation of the luminescence properties of $\mathrm{Mo}_{6}$ clusters after metathesis reaction (brightness of the emission and large stokes shifts). Similarly, with fluorinated hybrid compounds, irradiation with a blue or UV light induces a strong deep red emission. However, we noticed a specific behavior under constant irradiation of these new class of clustomesogen compared to their cesium salt precursors. Indeed, hybrid materials show a luminescence charging time corresponding to the time needed to reach the maximum of luminescence intensity after the first seconds of irradiation. This time was recorded on all clustomesogens in the LC state. To do so, samples were continuously irradiated at $365 \mathrm{~nm}$ and luminescence spectra were recorded at different timelaps during several hours (Figure 1).

Charging time is included between one minute for $\mathrm{Kat}_{2}\left[\mathrm{Mo}_{6} \mathrm{I}_{8}\left(\mathrm{OCOCF}_{3}\right)_{6}\right]$ and three minutes (for $\left.\mathrm{Kat}_{2}\left[\mathrm{Mo}_{6} \mathrm{I}_{8}\left(\mathrm{OCOC}_{2} \mathrm{~F}_{5}\right)_{6}\right]\right)$. Note that, surprisingly, $\mathrm{Kat}_{2}\left[\mathrm{Mo}_{6} \mathrm{I}_{8}\left(\mathrm{OCOCF}_{3}\right)_{6}\right]$ degrades under continuous irradiation as after one minute, its PL intensity decreases dramatically and was reduced by $45 \%$ after one hour. Hybrids(2) and (3), in the contrary, showed a very good stability under continuous irradiation (20h and $8 \mathrm{~h}$ half-life time respectively, see ESI Figure S9) and were therefore chosen to be incorporated in an optoelectronic device. At this point, we wish to state that although we already observed this charging time phenomenon when similar cluster units were embedded by a copolymerization process in a PMMA matrix, it is far from being well understood. At this stage, we may argue that irradiation of clusters decreases the local molecular $\mathrm{O}_{2}$ concentration within the material. The low permeability of the hybrid matrix to molecular oxygen could eventually explain this phenomenon. Indeed, the excited state of octahedral transition metal clusters is well known to produce singlet oxygen starting from molecular oxygen. ${ }^{[21]}$ As a result, the cluster luminescence is partially quenched. Very recently, we reported the copolymerization of the $\left[\mathrm{Mo}_{6} \mathrm{I}_{8} \mathrm{OCOC}_{2} \mathrm{~F}_{5}\right]^{2-}$ cluster unit at $50 \mathrm{wt} \%$ in a polyurethane nanocomposite. This matrix shows a very high gas permeability and absolute quantum yields of 0.1 and 0.7 were recorded in air and $\mathrm{N}_{2}$ atmosphere respectively. ${ }^{[2]}$ This point is also in good 
accordance with the absolute quantum yield (AQY) values calculated in a $\mathrm{N}_{2}$ atmosphere for our materials (see ESI Table S2). AQY were first determined in the glassy state in an air atmosphere using an integrating sphere. At first sight, obtained values appeared to be non-reproducible and were ranging from 0.25 up to 0.70 , whereas the cluster precursors were giving perfectly reproducible measurements with high AQY in the range of 0.3-0.4. Changing the atmosphere of the integrating sphere from air to $\mathrm{N}_{2}$ allowed us to obtain very reproducible measurements either for hybrid precursors, or for clustomesogens with largely increased AQY values of 0.7 .

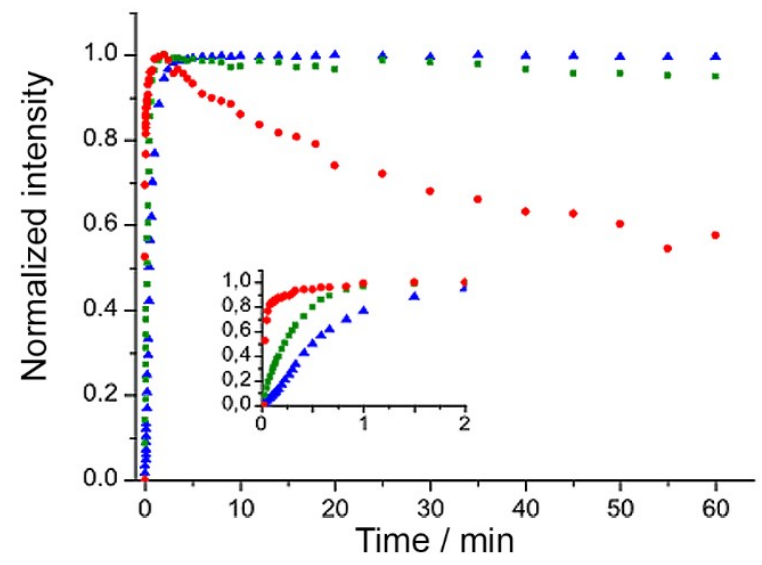

Figure 1. Evolution of the luminescence intensity upon constant irradiation during the first hour for $\mathrm{Kat}_{2}\left[\mathrm{Mo}_{6} \mathrm{I}_{8}\left(\mathrm{OCOCF}_{3}\right)_{6}\right]$ (diamonds), $\mathrm{Kat}_{2}\left[\mathrm{Mo}_{6} \mathrm{I}_{8}\left(\mathrm{OCOC}_{2} \mathrm{~F}_{5}\right)_{6}\right]$ (triangles) and $\mathrm{Kat}_{2}\left[\mathrm{Mo}_{6} \mathrm{I}_{8}\left(\mathrm{OCOC}_{3} \mathrm{~F}_{7}\right)_{6}\right]$ (squares)

Temperature dependent emission measurements were realized on samples deposited between two quartz slides to observe the influence of the self-assembling on the hybrids luminescence properties. Samples were heated at $100^{\circ} \mathrm{C}$ and slowly cooled down until $25^{\circ} \mathrm{C}$. Luminescence spectra were recorded every $1^{\circ} \mathrm{C}$ (Figure 2). As previously reported, if only non-radiative desexcitation is involved in the luminescence intensity variation, this last one should follow an exponential law of the type : $\mathrm{I}(\mathrm{T})=\mathrm{I}_{0} \exp (-\mathrm{A} / \mathrm{T})$ where $\mathrm{A}$ is constant and $\mathrm{I}_{0}$ the emission intensity at a given temperature (in our case: $300 \mathrm{~K}$ ). ${ }^{[23]} \mathrm{In}$ this case, reporting $\ln \left(\mathrm{I} / \mathrm{I}_{300}\right)$ $=\mathrm{f}(1 / \mathrm{T})$ should give a straight line and this is what is observed for the cesium salts of the anionic cluster unit precursors (inset figure 4, red line). For hybrids, the obtained curves significantly deviate from the straight line with a curvature at a temperature near to the isotropic to nematic transition temperature. Therefore, this indicates that, despite the isotropic nature of the emissive species, their integration in anisotropic hybrid supramolecular compounds leads to a significant change in the ability of the all material to emit light. These results demonstrate that temperature dependent luminescence studies are an efficient mean to detect phase transition temperatures within this class of hybrid nanomaterials. ${ }^{\left[{ }^{\circ c}\right]}$ Emission lifetime measurements were realized at $25^{\circ} \mathrm{C}$ i.e. within the nematic LC phase for all hybrids on samples deposited on a quartz slide. The spectroscopic $\left(\lambda_{\mathrm{em}}\right)$ and photophysical parameters (emission lifetime (amplitude $\left.=\mathrm{A}_{\mathrm{n}}\right)=\tau_{\mathrm{n}}(\mathrm{n}=2)$ ) calculated at $25^{\circ} \mathrm{C}$ are summarized in Table S2 and phosphorescence decay profiles presented in Figure S10. The data were fitted to a two exponential decay and the goodness of fit judged by the $\mathrm{R}^{2}$ values. All samples show a biexponential behavior with lifetimes around $5 \mu$ s and $50 \mu \mathrm{s}$. The calculated lifetime values are significantly shorter than the one usually calculated for $\left[\mathrm{Mo}_{6} \mathrm{I}_{8}\left(\mathrm{OCOC}_{\mathrm{n}} \mathrm{F}_{2 \mathrm{n}+1}\right)_{6}\right]^{2-}$ derivatives but are in good accordance with our previous reports when this type of cluster units is embedded in a polymer matrix. ${ }^{[22]}$ Indeed, Sokolov et al.$^{[13 a]}$ reported a monoexponential behavior at $25^{\circ} \mathrm{C}$ in $\mathrm{CH}_{3} \mathrm{CN}$ solution for $\left(\mathrm{nBu}_{4} \mathrm{~N}\right)_{2} \mathrm{Mo}_{6} \mathrm{I}_{8}\left(\mathrm{OCOC}_{3} \mathrm{~F}_{7}\right)_{6}$ with lifetime values of $303 \mu$ s while a lifetime value of $270 \mu \mathrm{s}$ was obtained in $\mathrm{CH}_{3} \mathrm{CN}$ solution for $\left(\mathrm{nBu}_{4} \mathrm{~N}\right)_{2} \mathrm{Mo}_{6} \mathrm{I}_{8}\left(\mathrm{OCOCF}_{3}\right)_{6}{ }^{[13 \mathrm{~b}]}$
Despite the nematic nature of the observed LC phases, hybrids are viscous which precludes their use in LC devices in their pure form. To overcome this problem, we integrated them into E7, a commercially available nematic LC matrix. Our choice was motivated by the facts that i) the chemical composition of this mixture is known. E7 contains the same mesogenic promoters (CB units) than the one we used to design our hybrid material. Therefore, a good miscibility and stability should be expected; ii) As E7 has a high birefringence $(0.21$ at $550 \mathrm{~nm})$ the molecular orientation should strongly influence the luminescence of the mixture. ; iii) E7 is one of the most popular LC mixture used in academic researches and thus a good reference to highlight the potential of our hybrid materials. ${ }^{[2]}$

a)
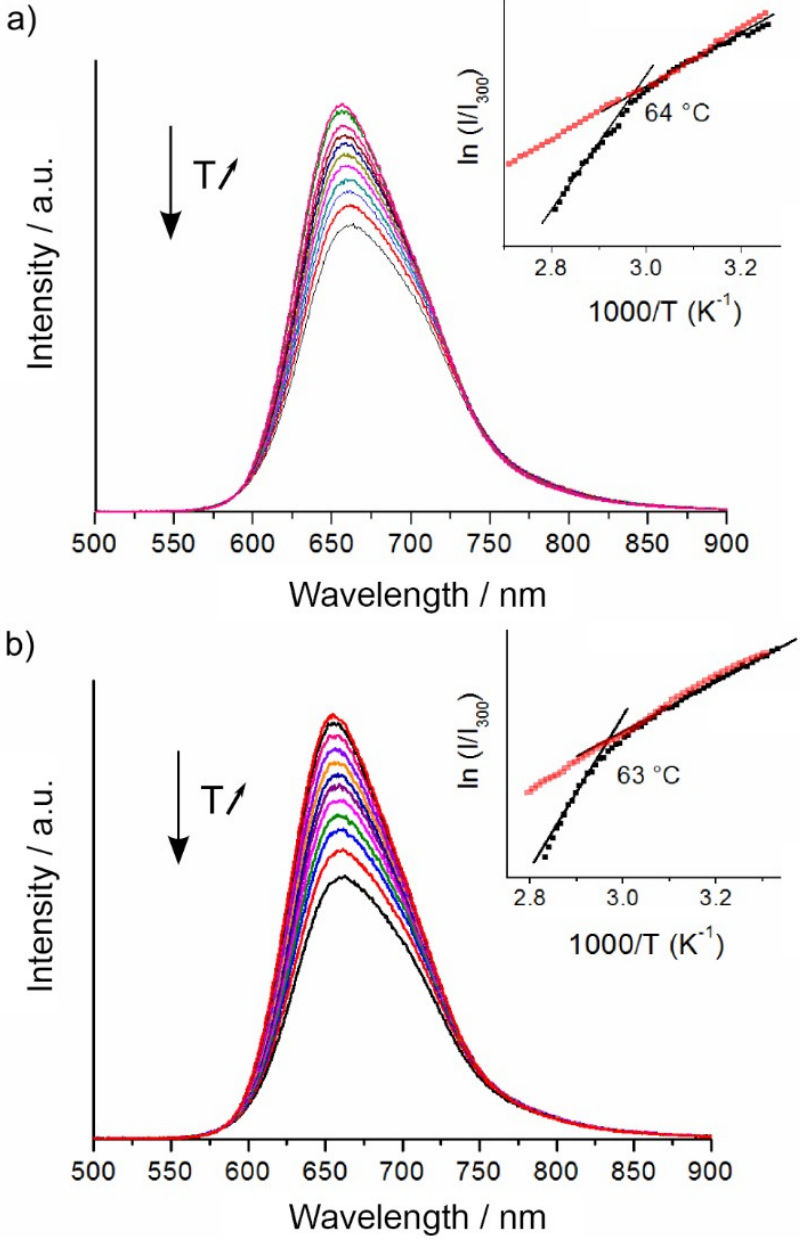

Figure 2. Temperature dependent emission spectra $(\lambda e x c=400 \mathrm{~nm})$ of $\mathrm{Kat}_{2}\left[\mathrm{Mo}_{6} \mathrm{I}_{8}\left(\mathrm{C}_{\mathrm{n}} \mathrm{F}_{2 \mathrm{n}+1} \mathrm{COO}\right)_{6}\right]$ a) $\left.\mathrm{n}=2, \mathrm{~b}\right) \mathrm{n}=3$. Inset : evolution of signal intensity at $656 \mathrm{~nm}$ in function of temperature for the hybrid (in black) and their respective cesium precursor (in red)

\subsection{Miscibility studies}

The miscibility of (2) and (3) with E7 and the influence of the hybrids concentration on the nematic to isotropic transition temperature were studied by POM and DSC and compared to pure E7 (see ESI Table S3 and Figure S11 for transition temperatures and phase diagrams). Due to the poor stability under continuous irradiation of (1), only a $10 \mathrm{wt} \%$ mixture was realized to confirm the nematic nature of its mesophase. Homogeneous mixtures were obtained by dissolving both components in a small amount of $\mathrm{CH}_{2} \mathrm{Cl}_{2}$ followed by solvent evaporation and drying. Mixtures melt to the liquid crystalline phase at about $-60^{\circ} \mathrm{C}$ and the isotropic phase appears around $60^{\circ} \mathrm{C}$ at a heating rate of $10^{\circ} \mathrm{C} / \mathrm{min}$. For all compositions, the second and third heating/cooling cycles were exactly reproducible indicating that the mixtures are thermally stable.

DSC Thermogram of E7 contains only one very broad transition both on heating and cooling cycles, extending on cooling from $58^{\circ} \mathrm{C}$ to $-62^{\circ} \mathrm{C}$. The onset of the isotropic to LC transition shows only little variation as a function of increasing clustomesogens concentration. For instance, the addition of $1 \mathrm{wt} \%$ or $20 \mathrm{wt} \%$ of $(3)$ induces a decrease of $1{ }^{\circ} \mathrm{C}$ or $3{ }^{\circ} \mathrm{C}$ 
respectively, which indicates that (3) is miscible with the commercial matrix and that E7 is only slightly destabilized by the introduction of clustomesogens. ${ }^{[25]}$ Indeed, no cluster aggregation was detected by microscopy under UV irradiation as depicted in Figure 3 which presents polarized optical micrographs (integration time: $100 \mathrm{~ms}$ ) of different $10 \mathrm{wt} \%$ mixtures taken at $25^{\circ} \mathrm{C}$. All mixtures remained stable over several months for all concentrations, allowing their incorporation into a LC cell.
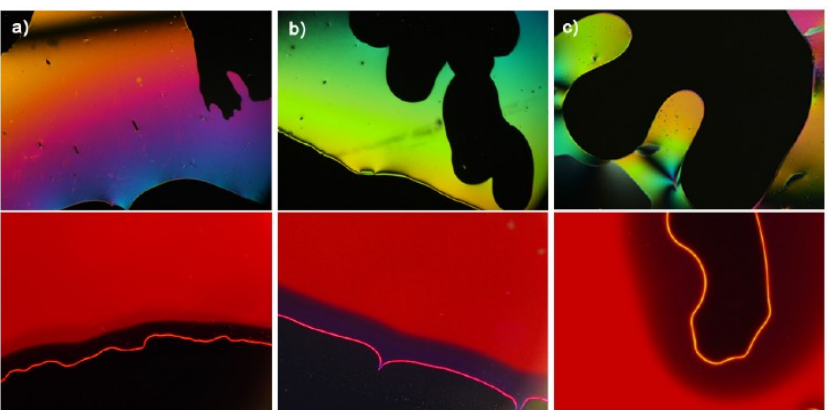

Figure 3. Polarized optical micrographs under white light (top) and irradiation at $350 \mathrm{~nm}$ (bottom) of clustomesogen : E7 mixtures (10 $\mathrm{wt} \%$ ) recorded at room temperature where clustomesogen corresponds to $\mathrm{Kat}_{2}\left[\mathrm{Mo}_{6} \mathrm{I}_{8}\left(\mathrm{C}_{\mathrm{n}} \mathrm{F}_{2 \mathrm{n}+1} \mathrm{COO}\right)_{6}\right]$ with a) $\mathrm{n}=1$, b) $\mathrm{n}=2$, c) $\mathrm{n}=3$.

At this stage, we wish to stress that the loading of clustomesogens onto E7 are very large compared to the usual loading of nanoparticles in commercial LC found in current literature. To the best of our knowledge, only Draper et al. used such large doping amount with gold functionalized NPs dispersed in $8 \mathrm{CB} \cdot{ }^{[25]}$ SAXS diffraction profiles obtained for a mixture of (3):E7 (1:9) confirmed that (3) does not segregate in E7 at such concentration (see ESI, Figure S12).

To get more insight on the clustomesogen behavior in the host LC matrix, we investigated the self-diffusion coefficient (D) by solid state NMR of (2) doped at $5 \mathrm{wt} \%$ in deuterated $5 \mathrm{CB}$ (the major component of E7 mixture). These coefficients are shown in Figure 4 in a temperature range above the clearing point of the solution, where the Stokes-Einstein law is expected to provide a reasonable model:

$D=\frac{k T}{6 \pi \eta R_{H}}$

where $\eta$ is the viscosity of the solution and $R_{H}$ the hydrodynamic radius of the diffusion molecule. The values measured for $5 \mathrm{CB}$ in the solution are very close to the ones of pure $5 \mathrm{CB}$ reported in the literature. ${ }^{[26]}$ According to equation (1):

$\eta_{\text {sol }}=\frac{D_{\text {purs }}}{D_{\text {sol }}} \eta_{\text {purs }} \sim 1.4 \eta_{\text {purs }}$

The viscosity of the $5 \mathrm{CB}$ isotropic phase is not strongly affected by the presence of the hybrid, at least for this concentration. Typical values of the hybrid self-diffusion coefficients range from $10^{-11}$ to $10^{-12} \mathrm{~m}^{2} / \mathrm{s}$. According again to the Stokes-Einstein law, we can express the hydrodynamic radius of the hybrid:

$\frac{R_{H, \text { hybrid }}}{R_{H, 5 C B}}=\frac{D_{5 C B \text { in solution }}}{D_{\text {hybrid in solution }}} \sim 5.1$

This ratio is surprisingly low as we could have expect at least a value higher than 6 . Indeed, (2) contains 6 CB units and a bulky cluster of $1.4 \mathrm{~nm}$ in diameter. This low value reflects that no aggregation of clustomesogens occurs in $5 \mathrm{CB}$ and that the electrostatic interactions involved in the supermolecular hybrid design are somehow lowering the total bulkiness by conferring additional mobility to the mesogenic arms. Typical thermal barriers to diffusion in the solution are about $28 \mathrm{~kJ} / \mathrm{mol}$, a value in close agreement with the ones reported for pure $5 \mathrm{CB} .{ }^{[26]}$

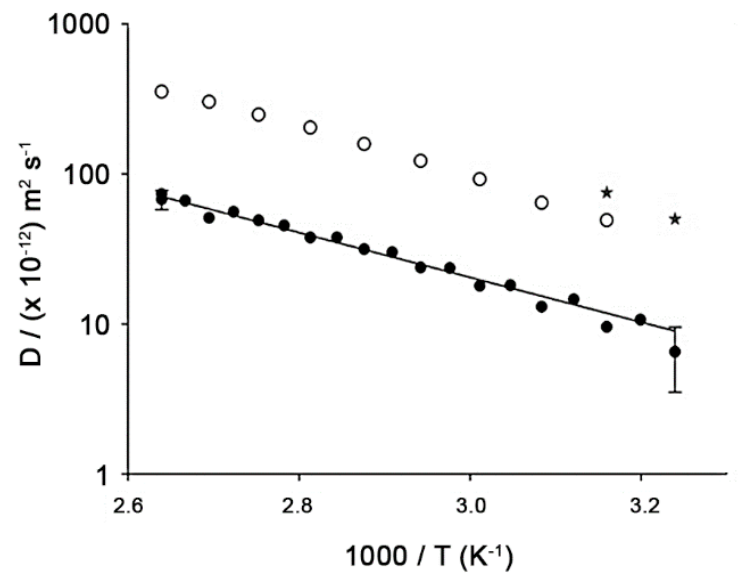

Figure 4. Self-diffusion coefficient of the hybrid (black dots) in a $5 \mathrm{wt} \%$ solution in perdeuterated $5 \mathrm{CB}$ compared to the self-diffusion coefficients of the 5CB solvent (open circles) and those of pure 5CB (stars, taken from ${ }^{[28]}$.

\subsection{Integration into electroswitchable device}

In a first attempt, all mixtures were integrated in the conventional twisted nematic LC cells (Figure 5a) of $5 \mu \mathrm{m}$ thickness. The influence of the clustomesogen concentration on the ability of mixtures to respond to the application of an external electric field was studied by looking at the shift in the required voltage corresponding to the Freedericksz transition, where the onset of switching of the LC molecule is observed. Doping E7 with clustomesogens slightly increased the Freedericksz transition threshold voltage $\left(\mathrm{V}_{\text {th }}\right)$ compared to that of pure E7, as shown in Table 2.

Table 2. Freederickzs transition field $\left(\mathrm{E}_{\mathrm{th}}\right)$ and operating field $\left(\mathrm{E}_{\mathrm{op}}\right)$ of mixtures containing E7 and hybrids at various concentrations.

\begin{tabular}{ccccc}
\hline $\begin{array}{c}\text { Concentration } \\
{[w+\%]}\end{array}$ & \multicolumn{2}{c}{$E 7:(2)$} & & \\
& & & & \\
& $E_{\text {th }}\left[\mathrm{V} . \llbracket m^{-1}\right]$ & $E_{\text {op }}\left[\mathrm{V} . \llbracket m^{-1}\right]$ & $E_{\text {th }}\left[\mathrm{V} . \llbracket m^{-1}\right]$ & $E_{\text {op }}\left[\mathrm{V} . \llbracket m^{-1}\right]$ \\
\hline 0 (pure E7) & 0.225 & 1.9 & 0.225 & 1.9 \\
1 & 0.225 & 1.9 & 0.225 & 1.9 \\
5 & 0.325 & 2.0 & 0.325 & 2.0 \\
10 & 0.375 & 2.0 & 0.385 & 2.0 \\
15 & 0.400 & 2.0 & 0.400 & 2.25 \\
20 & 0.450 & 2.25 & 0.475 & 2.25 \\
\hline
\end{tabular}

The increase in voltage level of the Freedericksz transition implies that the electrical polarizability of a microscopic unit volume inside the cell is reduced progressively by increasing the concentration of clustomesogen. The possible reason could be that the presence of octahedral molybdenum cluster units in the clustomesogen induces its symmetry up to a certain extent onto the nearest neighboring liquid crystal molecules constituting the unit volume. This microscopic behavioral change with concentration will be examined by dielectric spectroscopy in a future study. We also investigated the electro-optic contrast of our hybrid LC cells placed between crossed polarizers. Figure 5b shows that doping clustomesogens in E7 does not affect the alignment of the LC molecules 
up to $20 \mathrm{wt} \%$ and no biphasic area was observed even in presence of external voltage and switching between the on-state and off-state with a high contrast (see ESI for the corresponding videos). This switching behavior is not yet fully understood but we noticed that the optimized required voltage $\left(\mathrm{V}_{\mathrm{op}}\right)$ for full switching depends on the clustomesogen concentration (Table 2). We have observed that the clustomesogen:E7 system becomes electrochemically unstable by application of a higher voltage than $\mathrm{V}_{\mathrm{op}}$, to an extent that the system does not show switching anymore and looks black under crossed polarizer. This might be explained by the migration of ionic species toward the surface of the cell. As a result, the anchoring conditions of liquid crystal on the polymer surface could be modified, from planar to homeotropic orientation. Further experimentations to confirm this hypothesis will be performed. We also investigated the contrast between the off and on state. In our experimental conditions, we have recorded a 1:250 contrast in a twisted cell containing pure E7 against a 1:200 contrast for all the twisted cells containing E7 doped with (3). Possible reasons of this reduction in the contrast value in E7 hybrid cell could be that the octahedral symmetry of molybdenum clusters implies that the nematic ordering in the microscopic units volume is reduced, but most probably because the clustomesogen in the hybrid cells emits spontaneously $(600-900 \mathrm{~nm})$ under the white light used for contrast measurements. Indeed, clustomesogens absorb part of the visible spectrum and their emission can be observed with excitation wavelength ranging from $350 \mathrm{~nm}$ to nearly $550 \mathrm{~nm}$.

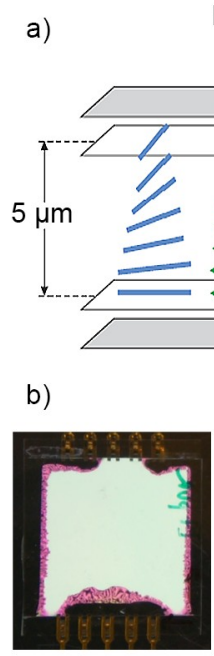

Off state Pure E7

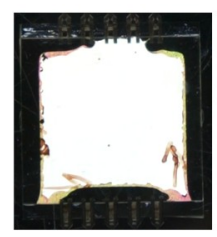

Off state

\section{Bright}
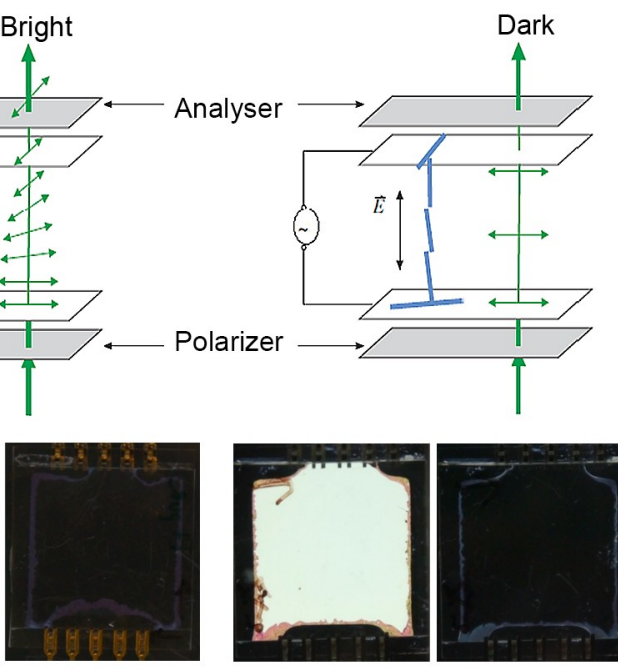

On state

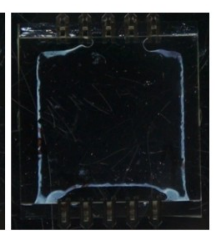

On state

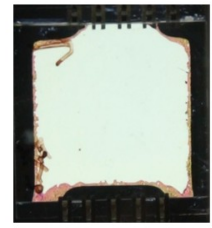

Off state 5 wt $\%$

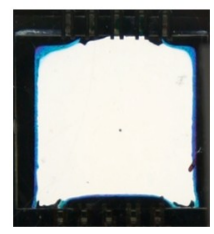

Off state 10 wt \% 20 wt \%

Figure 5. a) Switching mechanism of liquid crystal in a conventional twisted nematic cell geometry; b) Photographs showing the electrically controlled liquid-crystal orientation in twisted cells containing (3)/E7 mixtures at various concentrations.

We further measured the photoluminescence intensity modulation in LC cell containing the (3): E7 mixture at all concentration while switching between field-off $(0 \mathrm{~V})$ and field-on $(15 \mathrm{~V})$. In all cases, a decrease of around $45 \%$ in the photoluminescence intensity was observed upon application of the electric field (see ESI, Figure S13). This electrical switching is highly reversible, stable, and does not depend on the clustomesogen concentration within the E7 host. At this point, we wish to stress that, although we already observed a similar photoluminescence intensity switch with less luminescent clustomesogens doped in a E44 commercial LC matrix, ${ }^{[17]}$ this phenomenon is not yet fully understood. Indeed, the isotropy of the emissive metallic cluster cores should preclude, in principle, any anisotropic emission. Nonetheless, these experiments evidence that the all hybrid matrix has to be taken into account when one deals with its photoluminescence properties.

We finally investigated the dynamical response of all mixtures, specifically electrical time and relaxation time in uniformly aligned LC cell. Similar to the trend observed for Freederickzs transition, dynamical times increased with clustomesogen concentration (see ESI Table S4). In particular, we focused on relaxation time inherent to the LC molecules. This time is given by $\tau_{\text {off }}=\eta \mathrm{d}^{2} / \mathrm{K}$ with $\eta$ is rotational viscosity of LC, $d$ is the thickness of $\mathrm{LC}$ cell and $\mathrm{K}$ is the elastic constant. In our experiments, $\mathrm{d}$ and $\mathrm{K}$ remain constants $\left(\mathrm{d}=5 \mu \mathrm{m}\right.$ and $\left.\mathrm{K}=10^{-11} \mathrm{~N}\right)$. Thus, the viscosity $\eta$ has a linear evolution with the addition of (3) in the LC host.

\section{Conclusion}

We have presented in this work the synthesis and studies of three new clustomesogens obtained by ionic assembling. These hybrid supermolecular systems contain the highly luminescent $\left[\mathrm{Mo}_{6} \mathrm{I}_{8}\left(\mathrm{OCOC}_{\mathrm{n}} \mathrm{F}_{2 \mathrm{n}+1}\right)_{6}\right]^{2-}(\mathrm{n}=1,2,3)$ cluster units which confer them outstanding luminescence properties in the red NIR with AQY up to 0.7 in the LC state. All hybrids present a nematic behavior that is particularly rare for ionically assembled systems but that is a prerequisite to be inserted in an electro-controlled device. Photobleaching studies were realized under continuous irradiation at $360 \mathrm{~nm}$ and preclude the use of (1) that loses $45 \%$ of its intensity after only one hour. In the contrary (2) and (3) show a very good photostability over several hours of irradiation. Despite the nematic nature observed by POM, DSC and SAXS, hybrids (2) and (3) remain too viscous to be integrated directly in a device. To avoid this problem, we combined them with E7, a highly fluid and widely used LC material. Miscibility studies realized by POM and DSC have shown that mixtures are very stable even at very high concentration (up to $20 \mathrm{wt} \%$ ). Solid state NMR studies of (2) self-diffusion coefficient in deuterated $5 \mathrm{CB}$ confirmed that clustomesogens do not segregate in the $\mathrm{CB}$ containing LC material and that the ionic interactions used to maintain the supermolecular system maximize its mobility in the LC host. Mixtures at various percentage were introduced in twisted liquid crystal cells to determine the influence of the clustomesogen concentration on the E7 physical parameters such as the Frederickzs transition field, operating field, contrast ratio and their dynamical response. It turns out that, up to $10 \mathrm{wt} \%$ doping of clustomesogen, no significant changes are noted in the behavior of E7 toward the application of an electric field. Moreover, a reversible photoluminescent switch of around $45 \%$ has been observed in the LC cell upon application of a voltage under continuous irradiation whatever the doping concentration of the host E7 matrix. Finally, this first and full study, starting from the design and the synthesis of new molecular hybrid compounds and going up to their integration in an electro-controlled LC device, shows that clustomesogen containing fluorinated clusters are outstanding candidates to design new devices dedicated to optoelectronic applications.

\section{Experimental Section}

Experimental techniques. NMR spectra were recorded on a Brucker $400 \mathrm{P}$. All signals were referenced to the methyl signals of TMS at $\delta=0$ ppm. UV-Vis absorption measurements were performed on a Varian Cary 5000 UV-Vis-NIR spectrophotometer. Luminescence spectra were recorded with an ocean optic QE6500 photodetector mounted on the polarized optical microscope described below. Elemental Analysis were performed at the CRMPO with a Microanalyser Flash EA1112 CHNS/O Thermo Electron. Energy dispersive spectroscopy (EDS) was performed at CMEBA on a JEOL 6400 scanning electron microscope equipped with a XEDS Oxford field spectrometer. Polarized optical Microscopy and temperature dependent relative irradiance measurements were realized with a Nikon 80i polarized microscope equipped with a Linkam LTS420 hot stage, a Nikon Intensilight irradiation source, a Nikon DS-FI2 digital camera and an ocean optics QE6500 photodetector connected by optical fiber. In order to take into account the nonlinear sensitivity of the set up, it was calibrated with an Ocean Optics HL-2000-CAL Calibrated 6 
Tungsten Halogen Light Source. Two optical filters were used to select the excitation wavelength: either with a bandwidth: 330-380 $\mathrm{nm}$ or with a bandwidth $380-420 \mathrm{~nm}$. DSC measurements were realized at $10 \mathrm{~K} \cdot \mathrm{min}^{-1}$ with a DSC 200 F3 Maia NETSCH apparatus. X-Ray spectra are given as the scattering intensity versus the wavevector transfer $\mathrm{q}=4 \pi \sin (\theta)^{-1}\left(\AA^{-1}\right)$. X-ray scattering experiments were performed using a FR591 Bruker AXS rotating anode X-ray generator operated at $50 \mathrm{kV}$ and $50 \mathrm{~mA}$ with monochromatic $\mathrm{Cu} \mathrm{K \alpha}$ radiation $(\lambda=1.541 \AA)$ and point collimation. X-ray patterns were collected with a Mar345 ImagePlate detector (Marresearch, Norderstedt, Germany). The monochromatic $\mathrm{Cu} \mathrm{K} \alpha$ radiation $(\lambda=1.541 \AA)$ was directed with a $350 \mu \mathrm{m} \times 350 \mu \mathrm{m}$ focal spot at $320 \mathrm{~mm}$ by a double reflection on an elliptic cross multilayer Montel mirror (Incoatec, Geesthacht, Germany). The beam was defined under vacuum by four motorized carbon-tungsten slits (JJ-Xray, Roskilde, Denmark) positioned in front of the mirror $(500 \mu \mathrm{m} \times 500 \mu \mathrm{m})$. Four additional guard slits $(600 \mu \mathrm{m} \times 600 \mu \mathrm{m})$ were placed at the focal point with a $220 \mathrm{~mm}$ slit separation distance. The flux after the output mica windows was $3 \times 10^{8}$ photons $/ \mathrm{s}$. A $2 \mathrm{~mm}$ diameter square lead beam stop was placed under a vacuum at $270 \mathrm{~mm}$; afterward, the sample and the detector were positioned at $420 \mathrm{~mm}$. The X-ray patterns were therefore recorded for a range of reciprocal spacing $q=4 \pi \sin \theta / \lambda$ from 0.03 to $1.56 \AA^{-1}$, where $\theta$ is the diffraction angle. The repetition distances $d=2 \pi / \mathrm{q}$ should be between 200 and $4.0 \AA$. The samples were placed into $1.5 \mathrm{~mm}$ glass capillaries (GlasW.Müller, Germany) and introduced into a homemade capillary holder, which can maintain up to 20 capillaries at a controlled temperature. We use the programs Fit $2 \mathrm{D}$ and IgorPro to treat the data. ${ }^{[30]}$ The liquid crystal cells are made up by two glass plates covered by a $100 \Omega$ / square Indium Tin Oxide transparent electrode. A thin layer of polyimide was deposited by spin-coating on each substrate and cured at $180^{\circ} \mathrm{C}$. Both plates were rubbed in order to give a homogeneous alignment direction to the liquid crystal. A gasket of glue was deposited on the edge of one plate by a liquid dispenser and then, they were assembled and pressed. Spacers of $5 \mu \mathrm{m}$ were dispersed in the glue to force a gap of $5 \mu \mathrm{m}$ between the two plates. After UV curing of the gasket, the cells were filled by capillarity with liquid crystal mixture. Lifetime measurements were performed using APD110A Thorlabs Si avalanche photodiode and MPL-F-355 CNI 355 Q-switched laser with $\sim 7 \mathrm{~ns}-1 \mu \mathrm{J}$ pulses and $6 \mathrm{kHz}$ repetition rate. Traces were recorded using Lecroy 12 bit HDO4022 $200 \mathrm{MHz}$ oscilloscope with 1000 averaging. LC dynamic response measurements were performed using $633 \mathrm{~nm} \mathrm{He}-\mathrm{Ne}$ laser and two crossed polarizers. Traces were recorded using Tektronix TDS1002 oscilloscope. Voltage was applied by Teledyne Lecroy 2010 generator coupled to FLC Electronics A400DI amplifier. Contrast were measured using Newport 1830C photodiode. Electroswitchable device integrated luminescence was measured using PDA36A-EC Thorlabs Si avalanche photodiode and $405 \mathrm{~nm}$ $50 \mathrm{~mW}$ Oxxius laser diode circularly polarized impinging at $\sim 15^{\circ}$ incidence. For latter both measurements, luminescence was collected at normal incidence with numerical aperture of $\sim 0.16$ using parabolic mirrors, spectrally filtered with a high pass $500 \mathrm{~nm}$ filter and focused on the detector using another parabolic mirror. The device temperature was controlled using a MR-hei-TecHeidolph hotplate. Temperature was controlled with a $2{ }^{\circ} \mathrm{C}$ uncertainty. The luminescence quantum yields in the solid state were measured with a C9920-03 Hamamatsu system equipped with a $150 \mathrm{~W}$ xenon lamp, a monochromator, a Spectralon integrating sphere and a PMA-12 photomultiplier.

Synthesis. $\mathrm{Cs}_{2} \mathrm{Mo}_{6} \mathrm{I}_{14}$ and tris (w-[4-(4'-cyanobiphenylyl)oxy]decyl] methylammonium bromide (KAT-Br) were obtained by reported procedure with conform analytical data. ${ }^{[27]}$ Starting materials were purchased from Acros, Alfa Aesar and Aldrich, and used without further purification unless otherwise stated.

$\mathrm{Cs}_{2} \mathrm{Mo}_{6} \mathrm{I}_{8}\left(\mathrm{OCOCF}_{3}\right)_{6}$ : To a solution of $\mathrm{Cs}_{2} \mathrm{Mo}_{6} \mathrm{I}_{14}(1.5 \mathrm{~g}, 0.52 \mathrm{mmol})$ in $20 \mathrm{~mL}$ of acetone, was added a solution of silver trifluoroacetate $(0.760 \mathrm{~g}, 3.43 \mathrm{mmol})$ in $10 \mathrm{~mL}$ of acetone under argon. The mixture was left for $48 \mathrm{~h}$ in the dark and then was filtered through a Celite pad. The red solution was then evaporated to yield a red-orange powder. ${ }^{19}$ F-NMR (acetone- $\left.\mathrm{d}_{6}\right): \delta(\mathrm{ppm})=-82.98$. EDAX: Cs 2 , Mo 6, I 8, F 42, no Ag

$\mathrm{Cs}_{2} \mathrm{Mo}_{6} \mathrm{I}_{8}\left(\mathrm{C}_{2} \mathrm{~F}_{5} \mathrm{OCO}\right)_{6}$ : To a solution of $\mathrm{Cs}_{2} \mathrm{Mo}_{6} \mathrm{I}_{14}(1.5 \mathrm{~g}, 0.52 \mathrm{mmol})$ in $20 \mathrm{~mL}$ of acetone, was added a solution of silver pentafluoropropionate $(0.935 \mathrm{~g}, 3.42 \mathrm{mmol})$ in $10 \mathrm{~mL}$ of acetone under argon. The mixture was left for $48 \mathrm{~h}$ in the dark and then was filtered through a Celite pad. The red solution was then evaporated to yield a red-orange powder. ${ }^{19} \mathrm{~F}-\mathrm{NMR}$ $\left(\right.$ acetone- $\left.\mathrm{d}_{6}\right): \delta(\mathrm{ppm})=-82.98(3 \mathrm{~F}),-120.64(2 \mathrm{~F})$. ). EDAX: Cs 2, Mo 6.4, I 8.7, F 59.2, no Ag

$\mathrm{Cs}_{2} \mathrm{Mo}_{6} \mathrm{I}_{8}\left(\mathrm{OCOC}_{3} \mathrm{~F}_{7}\right)_{6}$ : To a solution of $\mathrm{Cs}_{2} \mathrm{Mo}_{6} \mathrm{I}_{14}(1.5 \mathrm{~g}, 0.57 \mathrm{mmol})$ in $20 \mathrm{~mL}$ of acetone, was added a solution of silver pentafluorobutyrate (1.1 $\mathrm{g}, 3.43 \mathrm{mmol}$ ) in $10 \mathrm{~mL}$ of acetone under argon. The mixture was left for $48 \mathrm{~h}$ in the dark and then was filtered through a Celite pad. The red solution was then evaporated to yield a red-orange powder. ${ }^{19} \mathrm{~F}-\mathrm{NMR}$ (acetone- $\left.\mathrm{d}_{6}\right): \delta(\mathrm{ppm})-81.47(3 \mathrm{~F}, \mathrm{~s}),-118.23(2 \mathrm{~F}, \mathrm{~s}),-127.32(2 \mathrm{~F}, \mathrm{~s})$. EDAX: Cs 2, Mo 6.0, I 7.1, F 48, no Ag

$\mathrm{Kat}_{2}\left[\mathrm{Mo}_{6} \mathrm{I}_{8}\left(\mathrm{OCOCF}_{3}\right)_{6}\right](\mathbf{1})$ : A solution of $\mathrm{Cs}_{2} \mathrm{Mo}_{6} \mathrm{I}_{8}\left(\mathrm{CF}_{3} \mathrm{COO}\right)_{6}(0.065 \mathrm{~g}$, $0.022 \mathrm{mmol}$ ) in acetone was added dropwise to a solution of Kat-Br $(0.051 \mathrm{~g}, 0.023 \mathrm{mmol})$ in dichloromethane. A white precipitate formed instantaneously. The mixture was stirred at reflux for $1 \mathrm{~h}$ and the white precipitate filtered through $\mathrm{Celite}^{\circledR}$. The solvent was evaporated to afford an orange oil. ${ }^{1} \mathrm{H}-\mathrm{NMR}\left(300 \mathrm{MHz}, \mathrm{CDCl}_{3}\right)$ : $1.34-1.39(72 \mathrm{H}, \mathrm{m}), 1.71-$ $1.83(24 \mathrm{H}, \mathrm{m}), 3.15(6 \mathrm{H}, \mathrm{s}), 3.26(12 \mathrm{H}, \mathrm{m}), 4.00(12 \mathrm{H}, \mathrm{t}, \mathrm{J}=6.6 \mathrm{~Hz})$, $6.99\left(12 \mathrm{H}_{\mathrm{Ar}}, \mathrm{d}, \mathrm{J}=8.7 \mathrm{~Hz}\right), 7.53\left(12 \mathrm{H}_{\mathrm{Ar}}, \mathrm{d}, \mathrm{J}=8.7 \mathrm{~Hz}\right), 7.66\left(24 \mathrm{H}_{\mathrm{Ar}}, \mathrm{q}, \mathrm{J}=\right.$ $8.4 \mathrm{~Hz}) .{ }^{19} \mathrm{~F}-\mathrm{NMR}\left(375 \mathrm{MHz}, \mathrm{CD}_{3} \mathrm{COCD}_{3}\right)$ : -83.02 (3F, s). EA: Found: $\mathrm{C}, 42.92 ; \mathrm{H}, 4.26 ; \mathrm{N}, 2.53 \% \mathrm{C}_{152} \mathrm{H}_{174} \mathrm{~N}_{8} \mathrm{O}_{18} \mathrm{~F}_{18} \mathrm{I}_{8} \mathrm{Mo}_{6}$ requires $\mathrm{C}, 42.13 ; \mathrm{H}$, 4.05; N, 2.59. EDS: Mo: 16.75; I: 18.12; F: 65.13; no bromine, no cesium.

$\mathrm{Kat}_{2}\left[\mathrm{Mo}_{6} I_{8}\left(\mathrm{OCOC}_{2} \mathrm{~F}_{5}\right)_{6}\right]$ (2): The same method as previously described was used with $\mathrm{Cs}_{2} \mathrm{Mo}_{6} \mathrm{I}_{8}\left(\mathrm{C}_{2} \mathrm{~F}_{5} \mathrm{COO}\right)_{6}(0.335 \mathrm{~g}, 0.118 \mathrm{mmol})$ and $\mathrm{Kat}-\mathrm{Br}$ $(0.261 \mathrm{~g}, 0.236 \mathrm{mmol})$. The product was obtained as an orange oil. ${ }^{1} \mathrm{H}-$ NMR $\left(300 \mathrm{MHz}, \mathrm{CDCl}_{3}\right): 1.34-1.39(72 \mathrm{H}, \mathrm{m}), 1.71-1.83(24 \mathrm{H}, \mathrm{m}), 3.05$ $(6 \mathrm{H}, \mathrm{s}), 3.17(12 \mathrm{H}, \mathrm{m}), 4.00(12 \mathrm{H}, \mathrm{t}, \mathrm{J}=6.6 \mathrm{~Hz}), 6.99\left(12 \mathrm{H}_{\mathrm{Ar}}, \mathrm{d}, \mathrm{J}=8.7\right.$ $\mathrm{Hz}), 7.53\left(12 \mathrm{H}_{\mathrm{Ar}}, \mathrm{d}, \mathrm{J}=8.7 \mathrm{~Hz}\right), 7.66\left(24 \mathrm{H}_{\mathrm{Ar}}, \mathrm{q}, \mathrm{J}=8.4 \mathrm{~Hz}\right) .{ }^{19} \mathrm{~F}-\mathrm{NMR}$ $\left(375 \mathrm{MHz}, \mathrm{CD}_{3} \mathrm{COCD}_{3}\right):-83.00(3 \mathrm{~F}, \mathrm{~s}),-120.61(2 \mathrm{~F}, \mathrm{~s})$. EA: Found: $\mathrm{C}$, 41.37; H, 3.83; N, $2.42 \% \mathrm{C}_{158} \mathrm{H}_{174} \mathrm{~N}_{8} \mathrm{O}_{18} \mathrm{~F}_{30} \mathrm{I}_{8} \mathrm{Mo}_{6}$ requires $\mathrm{C}, 40.95 ; \mathrm{H}$, 3.78; N, 2.42). EDS: Mo: 14.01; I: 16.05; F: 69.44; no bromine, no cesium.

$\mathrm{Kat}_{2}\left[\mathrm{Mo}_{6} \mathrm{I}_{8}\left(\mathrm{OCOC}_{3} \mathrm{~F}_{7}\right)_{6}\right]$ (3): The same method as previously described was used with $\mathrm{Cs}_{2} \mathrm{Mo}_{6} \mathrm{I}_{8}\left(\mathrm{C}_{2} \mathrm{~F}_{5} \mathrm{COO}\right)_{6}(0.400 \mathrm{~g}, 0.127 \mathrm{mmol})$ and $\mathrm{Kat}-\mathrm{Br}$ $(0.284 \mathrm{~g}, 0.255 \mathrm{mmol})$. The product was obtained as an orange oil. ${ }^{1} \mathrm{H}-$ NMR (300 MHz, $\left.\mathrm{CDCl}_{3}\right): 1.34-1.39(72 \mathrm{H}, \mathrm{m}), 1.71-1.83(24 \mathrm{H}, \mathrm{m}), 3.06$ $(6 \mathrm{H}, \mathrm{s}), 3.19(12 \mathrm{H}, \mathrm{m}), 4.00(12 \mathrm{H}, \mathrm{t}, \mathrm{J}=6.6 \mathrm{~Hz}), 6.99\left(12 \mathrm{H}_{\mathrm{Ar}}, \mathrm{d}, \mathrm{J}=8.7\right.$ $\mathrm{Hz}), 7.53\left(12 \mathrm{H}_{\mathrm{Ar}}, \mathrm{d}, \mathrm{J}=8.7 \mathrm{~Hz}\right), 7.66\left(24 \mathrm{H}_{\mathrm{Ar}}, \mathrm{q}, \mathrm{J}=8.4 \mathrm{~Hz}\right) .{ }^{19} \mathrm{~F}-\mathrm{NMR}$ (375 MHz, $\left.\mathrm{CD}_{3} \mathrm{COCD}_{3}\right)$ : -81.44 (3F, s), -118.17 (2F, s), -127.30 (2F, s). EA: Found: C, 37.87; H, 3.46; N, $2.09 \% \mathrm{C}_{164} \mathrm{H}_{174} \mathrm{~N}_{8} \mathrm{O}_{18} \mathrm{~F}_{42} \mathrm{I}_{8} \mathrm{Mo}_{6}+$ $5 \mathrm{CH}_{2} \mathrm{Cl}_{2}$ requires $\mathrm{C}, 37.68 ; \mathrm{H}, 3.05 ; \mathrm{N}, 2.08$. EDS: Mo: $10.91 ; \mathrm{I}: 12.13$; F: 75.02; no bromine, no cesium.

\section{Supporting Information}

Supporting Information is available from the Wiley Online Library or from the author.

\section{Acknowledgements}

This work has been done in the frame of ANR Clustomesogen : ANR13-BS07-0003-01 and fond de maturation FEDER Région Bretagne. Both organisms are acknowledged. Authors wish to thank Dr. F. Artzner and C. Mériadec for SAXS measurements and Dr. F. Camerel for DSC access. 
[1] D.-K. Yang, S.-T. Wu, Fundamentals of liquid crystal devices, John Wiley \& Sons, Ltd, 2006.

[2] J. W. Goodby, P. J. Collings, T. Kato, C. Tschierske, H. F. Gleeson, P. Raynes, Editors, Handbook of Liquid Crystals, Volume 8: Applications of Liquid Crystals, 2nd Edition, WileyVCH Verlag GmbH \& Co. KGaA, 2014.

[3] a) D. W. Bruce, D. A. Dunmur, E. Lalinde, P. M. Maitlis, P. Styring, Nature 1986, 323, 791; b) A. M. GiroudGodquin, P. M. Maitlis, Angew. Chem. Int. Ed. 1991, 30, 375; c) B. Donnio, D. Guillon, R. Deschenaux, D. W. Bruce, in Comprehensive Coordination Chemistry II: From Biology to Nanotechnology, Vol. 7 (Eds.: J. A. Mc Cleverty, J. J. Meyer, M. Fujita, A. Powell), Elsevier, Oxford, 2003, pp. 357; d) K. Binnemans, J. Mater. Chem. 2009, 19, 448.

[4] H. Coles, S. Morris, Nat. Photonics 2010, 4, 676.

[5] B. Donnio, D. Guillon, R. Deschenaux, D. W. Bruce, Comprehensive Coordination Chemistry II 2004, 7, 357.

[6] K. Binnemans, Chem. Rev. 2009, 109, 4283.

[7] a) H. Qi, T. Hegmann, Liq. Cryst. Today 2011, 20, 102; b) J. Mirzaei, M. Urbanski, K. Yu, H.-S. Kitzerow, T. Hegmann, J. Mater. Chem. 2011, 21, 12710; c) S. Saliba, Y. Coppel, P. Davidson, C. Mingotaud, B. Chaudret, M. L. Kahn, J.-D. Marty, J. Mater. Chem. 2011, 21, 6821; d) S. Saliba, Y. Coppel, C. Mingotaud, J.-D. Marty, M. L. Kahn, Chem. Eur. J. 2012, 18, 8084; e) S. Umadevi, X. Feng, T. Hegmann, Adv. Funct. Mater. 2013, 23, 1393; f) S. Umadevi, V. Ganesh, T. Hegmann, Vol. 6, Wiley-VCH Verlag GmbH \& Co. KGaA, 2014, pp. 27; g) C. Neaime, M. Prévôt, M. Amela-Cortes, V. Cîrcu, F. Grasset, H. Folliot, Y. Molard, Chem. Eur. J. 2014, 20, 17770.

[8] H. K. Bisoyi, S. Kumar, Chem. Soc. Rev. 2011, 40, 306. [9] a) S. K. Nayak, M. Amela-Cortes, C. Roiland, S. Cordier, Y. Molard, Chem. Commun. 2015, 51, 3774; b) M. AmelaCortes, F. Dorson, M. Prévôt, A. Ghoufi, B. Fontaine, F. Goujon, R. Gautier, V. Cîrcu, C. Mériadec, F. Artzner, H. Folliot, S. Cordier, Y. Molard, Chem. Eur. J. 2014, 20, 8561; c) M. Amela-Cortes, S. Cordier, N. G. Naumov, C. Meriadec, F. Artzner, Y. Molard, J. Mater. Chem. C 2014, 2, 9813; d) Y. Molard, A. Ledneva, M. Amela-Cortes, V. Circu, N. G. Naumov, C. Meriadec, F. Artzner, S. Cordier, Chem. Mater. 2011, 23, 5122; e) A. S. Mocanu, M. AmelaCortes, Y. Molard, V. Circu, S. Cordier, Chem. Commun. 2011, 47, 2056; f) Y. Molard, F. Dorson, V. Circu, T. Roisnel, F. Artzner, S. Cordier, Angew. Chem. Int. Ed. 2010, 49, 3351.

[10] a) F. A. Cotton, Met. Clusters Chem. 1999, 1, 3; b) F. A. Cotton, Inorg. Chem. 1964, 3, 1217.

[11] a) A. W. Maverick, J. S. Najdzionek, D. MacKenzie, D. G. Nocera, H. B. Gray, J. Am. Chem. Soc. 1983, 105, 1878; b) A. W. Maverick, H. B. Gray, J. Am. Chem. Soc. 1981, 103, 1298.

[12] a) S. Cordier, Y. Molard, K. A. Brylev, Y. V. Mironov, F. Grasset, B. Fabre, N. G. Naumov, J. Cluster Sci. 2015, 26, 53; b) S. Cordier, F. Grasset, Y. Molard, M. Amela-Cortes, R. Boukherroub, S. Ravaine, M. Mortier, N. Ohashi, N. Saito, H. Haneda, J. Inorg. Organomet. Polym. Mater. 2015, 25, 189; c) Y. Molard, C. Labbe, J. Cardin, S. Cordier, Adv. Funct. Mater. 2013, 23, 4821; d) F. Grasset, Y. Molard, S. Cordier, F. Dorson, M. Mortier, C. Perrin, M. Guilloux-Viry, T. Sasaki, H. Haneda, Adv. Mater. 2008, 20, 1710; e) F. Grasset, F. Dorson, S. Cordier, Y. Molard, C. Perrin, A.-M. Marie, T. Sasaki, H. Haneda, Y. Bando, M. Mortier, Adv. Mater. 2008, $20,143$.

[13] a) M. N. Sokolov, M. A. Mihailov, E. V. Peresypkina, K. A. Brylev, N. Kitamura, V. P. Fedin, Dalton Trans. 2011, 40, 6375; b) K. Kirakci, P. Kubat, M. Dusek, K. Fejfarova, V. Sicha, J. Mosinger, K. Lang, Eur. J. Inorg. Chem. 2012, 3107.

[14] a) M. D. Everaars, A. T. M. Marcelis, A. J. Kuijpers, E. Laverdure, J. Koronova, A. Koudijs, E. J. R. Sudholter, Langmuir 1995, 11, 3705; b) M. Amela-Cortes, S. Cordier, N. G. Naumov, C. Mériadec, F. Artzner, Y. Molard, J. Mater. Chem. C 2014, 2, 9813.

[15] E. Terazzi, G. Rogez, J.-L. Gallani, B. Donnio, J. Am. Chem. Soc. 2013, 135, 2708.

[16] D. W. Bruce, S. A. Hudson, J. Mater. Chem. 1994, 4,
[17] M. Prevot, M. Amela-Cortes, S. K. Manna, S. Cordier, T. Roisnel, H. Folliot, L. Dupont, Y. Molard, J. Mater. Chem. C 2015, 3, 5152.

[18] a) B. Bilgin-Eran, C. Tschierske, S. Diele, U. Baumeister, $J$. Mater. Chem. 2006, 16, 1136; b) B. Bilgin-Eran, C. Tschierske, S. Diele, U. Baumeister, J. Mater. Chem. 2006, 16, 1145; c) G. Johansson, V. Percec, G. Ungar, K. Smith, Chem. Mater. 1997, 9, 164.

[19] a) W. Li, S. Y. Yi, Y. Q. Wu, L. X. Wu, J. Phys. Chem. B 2006, 110, 16961; b) W. Li, S. Y. Yin, J. F. Wang, L. X. Wu, Chem. Mater. 2008, 20, 514; c) J. W. Goodby, I. M. Saez, S. J. Cowling, V. Gortz, M. Draper, A. W. Hall, S. Sia, G. Cosquer, S. E. Lee, E. P. Raynes, Angew. Chem. Int. Edit. 2008, 47, 2754.

[20] K. V. Axenov, S. Laschat, Materials 2011, 4, 206.

[21] J. A. Jackson, C. Turro, M. D. Newsham, D. G. Nocera, J. Phys. Chem. 1990, 94, 4500.

[22] M. Amela-Cortes, S. Paofai, S. Cordier, H. Folliot, Y. Molard, Chem. Commun. 2015, 51, 8177.

[23] a) S. Suarez, O. Mamula, D. Imbert, C. Piguet, J. C. G. Bunzli, Chem. Commun. 2003, 1226; b) N. Kitamura, Y. Ueda, S. Ishizaka, K. Yamada, M. Aniya, Y. Sasaki, Inorg. Chem. 2005, 44, 6308. [24] J. Li, G. Baird, Y.-H. Lin, H. Ren, S.-T. Wu, J. Soc. Inf. Display 2005, 13, 1017.

[25] M. Draper, I. M. Saez, S. J. Cowling, P. Gai, B. Heinrich, B. Donnio, D. Guillon, J. W. Goodby, Adv. Funct. Mater. 2011, 21, 1260.

[26] S. V. Dvinskikh, I. Furo, H. Zimmermann, A. Maliniak, Phys. Rev. E: Stat., Nonlinear, Soft Matter Phys. 2002, 65, 061701/1.

[27] a) K. Kirakci, S. Cordier, C. Perrin, Z. Anorg. Allg. Chem. 2005, 631, 411; b) M. D. Everaars, A. T. M. Marcelis, E. J. R. Sudholter, Colloid Surface A 1995, 102, 117. 